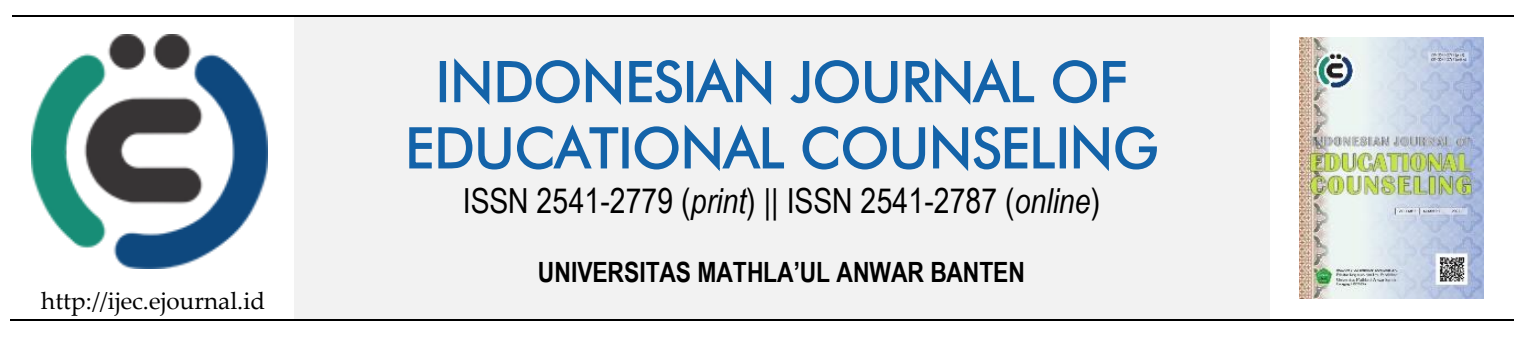

Research Based Article

\title{
Mengatasi Perilaku Bullying Siswa Melalui Konseling Kelompok Teknik Role Playing
}

\author{
Muhammad Asroㅁ, DYP Sugiharto², Awalya ${ }^{2}$ \\ ${ }^{1}$ SMK Negeri 1 Terisi, Indramayu, Jawa Barat, Indonesia \\ ${ }_{2}^{2}$ Universitas Negeri Semarang, Indonesia
}

\begin{tabular}{ll}
\hline Article History & ABSTRACT \\
\hline Received: 06.05.2021 & OVERCOMING STUDENT BULLYING BEHAVIOUR THROUGH ROLE- \\
Received in revised form: & PLAYING TECHNIQUE GROUP COUNSELING. This study aims to determine \\
25.06 .2021 & the impact of group counselling on role-playing techniques on student bullying \\
Accepted: 01.07 .2021 & behaviour at SMP Negeri 1 Terisi Indramayu. The pretest-posttest non- \\
Available online: 30.07 .2021 & equivalent control group experimental design was used in this study by \\
& involving a total of 14 students of class VIII who were selected using the \\
& purposive sampling technique as participants and divided into two groups. \\
& Bullying behaviour data were collected through a form of bullying scale- \\
& perpetration. The data analysis technique used is nonparametric statistics using \\
& the Wilcoxon test with a significant level of $5 \%$. The results showed that there \\
& was a significant decrease in bullying behaviour in the experimental group \\
& (M=18.71) compared to the control group (M=33.43).
\end{tabular}

KEYWORDS: Bullying Behaviour, Group Counseling, Role-Playing.

DOI: $10.30653 / 001.202152 .174$

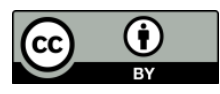

This is an open access article distributed under the terms of the Creative Commons Attribution 4.0 International License, which permits unrestricted use, distribution, and reproduction in any medium, provided the original work is properly cited. (0) 2021 Muhammad Asro, DYP Sugiharto, Awalya.

\section{PENDAHULUAN}

Remaja merupakan masa transisi dari anak-anak menuju dewasa disertai dengan pertumbuhan dan perkembangan diri. Perkembangan diri remaja sering mendapatkan gangguan kasus kekerasan, yakni diantaranya bullying. Hal ini sesuai dengan penelitian yang dilakukan Sari, (2010) menerangkan bahwa 50,89\% pelajar laki-laki dan 49,10\% pelajar perempuan dari 167 sampel penelitian pada salah satu SMA di Bogor mengalami kekerasan bullying. Hal serupa juga terjadi pada penelitian dari Caravaca Sánchez et al., (2016) menemukan angka yang besar dalam kasus kekerasan bullying dikalangan pelajar, sejumlah 543 pelajar 62,3\% siswa melaporkankan diri menjadi korban bullying, 52,7\% siswa melaporkan diri menjadi korban cyberbullying dan 40,7 \% melaporkan diri menjadi korban bullying dan cyberbullying. Penelitian terbaru juga masih menemukan banyaknya

\footnotetext{
${ }^{1}$ Corresponding author's address: Kiajaran Kulon RT. 05 RW. 03 Kecamatan Lohbener Kabupaten Indramayu Jawa Barat, 45252 E-mail: asroboy950101@gmail.com
} 
kasus kekerasan bullying pada remaja, hampir setengah dari 556 siswa dari 6 sekolah menjadi korban bullying di sekolah (Ahmed, Ahmed \& Hiramoni, 2021).

Secara umum bullying didefinisikan sebagai perilaku agresif berulang kali yang di dalamnya terdapat ketidakseimbangan kekuatan antara kedua pihak (Nansel et al., 2001; Olweus, 1993). Menurut Swearer, S.M \& Hymel, (2015) bullying adalah sesuatu yang unik, tapi juga sesuatu yang kompleks dari agresif hubungan interpersonal yang memiliki banyak bentuk dan fungsi serta dimanifestasikan dalam berbagai bentuk hubungan. Sedangkan menurut Coloroso, (2007) bullying merupakan perbuatan atau perkataan yang menimbulkan rasa takut, sakit atau tertekan baik secara fisik maupun mental yang dilakukan secara terencana oleh pihak yang merasa lebih berkuasa terhadap pihak yang dianggap lebih lemah. Pada penelitian selanjutnya, ada perkembangan definisi yang dilakukan oleh Volk, Dane, \& Marini, (2014) dalam penelitiannya mengusulkan perbaruan definisi berdasarkan teori pemersatu yang mencakup konteks ekologi evolusioner yaitu "bullying adalah perilaku diarahkan untuk tujuan agresif yang membahayakan individu lain dalam konteks ketidakseimbangan kekuatan". Dalam konteks tersebut ada tiga kriteria suatu perilaku bisa dikatakan sebagai kekerasan bullying yakni pengarahan tujuan yang bersifat agresif, ketidakseimbangan kekuatan antara pelaku dan korban, terakhir bahaya yang ditimbulkan dari perilaku bullying.

Dampak perilaku bullying baik sebagai korban, pelaku ataupun keduanya mendapatkan dampak kesehatan mental yang buruk seperti kecemasan depresi, kesulitan psikosoial bahkan melukai diri (Eyuboglu, M et al, 2021). Kasus tewasnya siswi SMA bernama Audrey pada tahun 2018 yang mengalami kekerasan bullying oleh 3 orang temannya yang merupakan siswi SMP menjadi catatan hitam bagi Komisi Perlindungan Anak Indonesia (KPAI). Sehingga KPAI menegaskan bahwa kekerasan bullying di dunia pendidikan menempati urutan keempat dalam kasus kekerasan terhadap anak Indonesia.

Oleh karena itu perlu adanya penanggulangan perilaku bullying siswa supaya tidak ada pihak yang dirugikan. Konseling kelompok hadir dan memberikan bukti dapat meredukasi perilaku bullying siswa. Konseling kelompok merupakan pengembangan hubungan interpersonal antara individu dengan bertatap muka yang ditandai dengan adanya kepercayaan, penerimaan, rasa hormat, kehangatan, komunikasi dan pemahaman melalui konselor dan seluruh anggota kelompok untuk saling membantu dan memenuhi tujuan kelompok dan menemukan, memahami dan menerapkan cara-cara mencapai tujuan yang melekat dalam pembentukan dan tujuan kelompok (Trotzer, 2006). Menurut Gazda dalam Berg, Landreth, \& Fall, (2018) konseling kelompok dapat memberi individu dengan jenis pengalaman kelompok yang membantu mereka belajar untuk berfungsi secara efektif, untuk mengembangkan toleransi terhadap stres dan kecemasan, dan untuk menemukan kepuasan dalam bekerja dan hidup dengan orang lain.

Hasil temuan penelitian mengungkapkan konseling REBT dengan teknik role playing dianggap cocok dan efektif dalam menurunkan sikap agresif dan perilaku bullying siswa (Yahya \& Mustaffa, 2012). Namun penelitian tersebut tidak mencantumkan secara jelas metode apa yang dipakai dalam penelitian serta tidak adanya kejelasan seberapa besar perubahan perilaku yang terjadi terhadap perilaku konseli. Peneliti tertarik menguji kembali pendekatan REBT (Rational Emotive Behavior Therapy) dengan teknik role playing dalam format konseling kelompok untuk membuktikan bahwa teori tersebut mampu menurunkan perilaku bullying siswa dengan memaparkan secara jelas metode dan perubahan perilaku sebelum dan sesudah dilakukan perlakuan terhadap konseli. Alasan peneliti menggunakan pendekatan REBT dengan teknik role playing 
karena teknik ini diasumsikan peneliti sangat sesuai dengan penanganan bullying mengingat teknik ini mencakup tiga perubahan: rasional, emotif dan perilaku kearahan positif. Teknik role playing sangat menguntungkan bagi konselor karena dapat mengekplorasi kemungkinan blok kognitif, emotif atau perilaku serta bereksperimen dengan berbagai solusi untuk interaksi pada tahap selanjutnya kepada anggota kelompok ketika memerankan peran dalam kegiatan konseling kelompok (Ellis \& McLaren, 1998: 80).

Selanjutnya penelitian yang dilakukan oleh Purnaningrum, Purwanto \& Ja'far (2017) menunjukan hasil yang positif dalam membentuk sikap negatif siswa terhadap perilaku bullying dengan menggunakan teknik role playing dalam format konseling kelompok dengan menekankan muatan empati. Siswa diminta untuk melakukan peran nyata dalam kehidupan sehari-hari dengan mengajarkan kepada siswa berbagai keterampilan dengan tujuan menekankan perubahan sikap untuk lebih bersikap negatif dalam perilaku bullying di sekolah. Penerapan konseling kelompok dengan teknik role playing dengan muatan empati mampu meningkatkan sikap negatif siswa terhadap perilaku bullying yang sebelumya membentuk sikap positif terhadap perilaku bullying. Tujuan penelitian tersebut berfokus hanya untuk mengubah sikap positif terhadap perilaku bullying bukan langsung merubah perilaku bullying siswa yang mana bersifat preventif dalam mengurangi perilaku bullying dengan memasukan muatan empati dalam teknik role playing, oleh karenanya peneliti ingin memperluas penelitian kearah subjek siswa yang melakukan perilaku bullying.

Peneliti ingin menggunakan konseling kelompok dalam mengurangi perilaku bullying siswa dengan menggunakan teknik role playing. Teknik role playing mengajarkan kepada siswa berbagai keterampilan seperti bersosialisasi, spontanitas, dan kreativitas secara langsung dalam kelompok dengan cara memerankan suatu peran yang nyata dalam kehidupan sehari-hari. Peranan siswa dalam konseling kelompok dibawa seperti keadaan dimana pelaku bullying menjadi korban bullying dan merasa bersalah sehingga ia tidak ingin mengulangi perilaku tersebut, metode ini biasa disebut dalam teknik role playing yakni metode mirror.

Berdasarkan penelitian dan fenomena serta definisi bullying diatas, peneliti menyimpulkan bahwa masih banyak terjadinya kekerasan bullying dalam dunia pendidikan. Hasil studi awal yang dilakukan peneliti pada bulan Mei 2020 terhadap 50 siswa SMP Negeri 1 Terisi Kabupaten Indramayu dengan menyebarkan angket perilaku bullying yang disebarkan secara acak. Menunjukan bahwa dari 50 siswa, terdapat 5 siswa dalam kategori tinggi dengan rata-rata 10\%, sedangkan 13 siswa berada dalam kategori sedang dengan rata-rata $26 \%$, kemudian 16 siswa berada dalam kategori rendah dengan rata-rata $32 \%$ dan terdapat 16 siswa dalam ketegori sangat rendah dengan rata-rata $32 \%$.

Temuan lain dalam studi awal ditemukan bahwa tidak adanya guru BK di sekolah tersebut, sehingga pelayanan bimbingan dan konseling seringkali dilakukan oleh kesiswaan dan pembina OSIS yang bukan merupakan keahlian dan wewenang mereka. Sehingga hasil dari pelayanan kurang mengoptimalkan perkembangan peserta didik khusunya dalam penanganan perilaku bullying siswa yang lebih terpaku dengan tata tertib dan sanksi sekolah dibandingkan dengan sentuhan psikis. Dapat disimpulkan bahwa pemberian layanan bimbingan dan konseling sangat penting khusunya dalam penanganan kasus bullying dan harus dilakukan oleh guru BK. Sehingga dapat menyentuh psikis siswa dan dapat mengoptimalkan perkembangan peserta didik. Oleh 
karena itu peneliti tertarik untuk menganalisis menerapkan konseling kelompok teknik role playing dalam mengurangi perilaku bulllying siswa di SMP N 1 Terisi.

\section{METODE}

Metode penelitian ini menggunakan pretest-posttest non equivalent countrol group design. Subjek penelitian ini adalah seluruh siswa kelas VIII SMP Negeri 1 Terisi berjumlah 209 siswa yang diambil dengan menggunakan teknik purposive sampling. Sejumlah 14 siswa yang memiliki perilaku bullying tinggi diambil sebagai sampel penelitian dan dibagi menjadi dua kelompok, yakni kelompok eksperimen dan kelompok kontrol dengan masing-masing beranggotakan 7 siswa. Kelompok eksperimen diberikan perlakuan konseling kelompok teknik role playing selama 6 kali pertemuan dengan durasi 2x45 menit, sedangkan kelompok kontrol hanya diberikan konseling kelompok konvensional selama 4 kali pertemuan dengan durasi $1 \times 45$ menit. Kelompok eksperimen terdiri dari 4 anak laki-laki dan 3 perempuan, begitu juga kelompok kontrol terdiri dari 4 anak laki-laki dan 3 perempuan.

Intrumen yang digunakan dalam pengumpulan data adalah skala the form bullying scale-perpetration dengan aspek-aspek dari Shaw, T et al., (2013), yaitu bulllying fisik, verbal, relasi, ancaman dan sosial yang terdiri dari 10 item dengan 5 tingkat penskalaan ( 1 = sangat tidak sesuai, 4 = sangat sesuai). Berdasarkan hasil uji validitas kepada 50 respon yang kondisinya mirip dengan subjek penelitian didapatkan 10 item yang valid. Sedangkan hasil uji reabilitas dengan menggunakan uji statistik cronbach alpha menunjukkan bahwa koefisiensi sebesar 0,867 .

\section{HASIL DAN PEMBAHASAN}

Dalam penelitian ini analisis deskriptif kuantitatif yang digunakan melalui perhitungan rata-rata (mean) dan standar deviasi (SD). Analisis ini digunakan untuk melihat tingkat perilaku bullying siswa sebelum (pre-test) dan setelah diberikan intervensi (posttest).

Tabel 1. Tingkat Perilaku Bullying Siswa pada Konseling Kelompok Teknik Role Playing

\begin{tabular}{lcccccc}
\hline \multirow{2}{*}{ Kelompok } & \multicolumn{2}{c}{ Pretest } & \multicolumn{2}{c}{ Posttest } & \multirow{2}{*}{$Z$} & \multirow{2}{*}{$\mathrm{P}$} \\
\cline { 2 - 5 } & $\mathrm{M}$ & $\mathrm{SD}$ & $\mathrm{M}$ & $\mathrm{SD}$ & & \\
\hline Eksperimen & 39 & 3 & 18 & 4 & -2.375 & $<0,05$ \\
Kontrol & 37 & 1 & 33 & 2 & -2.375 & $<0,05$ \\
\hline Ket: Z = Uji Wilcoxon & $\mathrm{M}=$ Median & $P=$ Signifikan & &
\end{tabular}

Tabel 1 menunjukan bahwa uji wilcoxon variabel perilaku bullying pada kelompok eksperimen menunjukkan nilai $(\mathrm{z}=-2.375 ; p<0.05)$. Besarnya nilai tersebut menunjukkan bahwa terdapat penurunan perilaku bullying yang signifikan setelah diberi konseling kelompok teknik role playing. Sedangkan pada kelompok kontrol miliki nilai $(\mathrm{z}=-2.375$; $p<0.05)$, nilai tersebut menjelaskan bahwa penurunan perilaku bullying yang dialami signifikan. Berdasarkan hasil uji wilcoxon pada variable perilaku bullying kedua kelompok sama-sama efektif dalam menurunkan perilaku bullying. Namun berdasarkan rata-rata skor perilaku bullying pada kelompok eksperimen $(\mathrm{M}=18)$ lebih kecil dari pada kelompok kontrol $(\mathrm{M}=33)$. Sehingga pada kelompok eksperimen lebih efektif menurunkan perilaku bullying dibandingkan pada kelompok kontrol. Untuk mempermudah pembaca, peneliti paparkan kategori hasil pre-test dan post-test sebagai berikut: 
Tabel 2. Kategori Perilaku Bullying Kelompok Eksperimen

\begin{tabular}{|c|c|c|c|c|c|c|c|c|}
\hline \multirow[b]{2}{*}{ No } & \multirow[b]{2}{*}{$\begin{array}{l}\text { Kode } \\
\text { Responden }\end{array}$} & \multicolumn{3}{|l|}{ Pre Test } & \multicolumn{3}{|c|}{ Post Test } & \multirow[b]{2}{*}{$\begin{array}{l}\text { Selisih } \\
\text { Skor }\end{array}$} \\
\hline & & $\begin{array}{l}\text { Jumlah } \\
\text { Skor }\end{array}$ & $\%$ & Kategori & $\begin{array}{l}\text { Jumlah } \\
\text { Skor }\end{array}$ & $\%$ & Kategori & \\
\hline 1 & K-1 & 46 & 92 & $\begin{array}{l}\text { Sangat } \\
\text { Tinggi }\end{array}$ & 22 & 44 & Rendah & 24 \\
\hline 2 & K-2 & 39 & 78 & Tinggi & 25 & 50 & Rendah & 14 \\
\hline 3 & K-3 & 39 & 78 & Tinggi & 15 & 30 & $\begin{array}{l}\text { Sangat } \\
\text { Rendah }\end{array}$ & 24 \\
\hline 4 & $\mathrm{~K}-4$ & 38 & 76 & Tinggi & 17 & 34 & $\begin{array}{l}\text { Sangat } \\
\text { Rendah }\end{array}$ & 21 \\
\hline 5 & $\mathrm{~K}-5$ & 37 & 74 & Tinggi & 19 & 38 & Rendah & 18 \\
\hline 6 & K-6 & 39 & 78 & Tinggi & 13 & 26 & $\begin{array}{l}\text { Sangat } \\
\text { Rendah }\end{array}$ & 26 \\
\hline 7 & $\mathrm{~K}-7$ & 36 & 72 & Tinggi & 19 & 38 & Rendah & 17 \\
\hline Rata & rata & 39,14 & 78,28 & Tinggi & 18,57 & 37,14 & Rendah & \\
\hline
\end{tabular}

Tabel 3. Kategori Perilaku Bullying Kelompok Kontrol

\begin{tabular}{|c|c|c|c|c|c|c|c|c|}
\hline \multirow[b]{2}{*}{ No } & \multirow[b]{2}{*}{$\begin{array}{l}\text { Kode } \\
\text { Responden }\end{array}$} & \multicolumn{3}{|l|}{ Pre Test } & \multicolumn{3}{|c|}{ Post Test } & \multirow[b]{2}{*}{$\begin{array}{l}\text { Selisih } \\
\text { Skor }\end{array}$} \\
\hline & & $\begin{array}{l}\text { Jumlah } \\
\text { Skor }\end{array}$ & $\%$ & Kategori & $\begin{array}{l}\text { Jumlah } \\
\text { Skor }\end{array}$ & $\%$ & Kategori & \\
\hline 1 & $\mathrm{~K}-1$ & 36 & 72 & Tinggi & 22 & 68 & Sedang & 24 \\
\hline 2 & $\mathrm{~K}-2$ & 41 & 82 & Tinggi & 25 & 72 & Tinggi & 14 \\
\hline 3 & $\mathrm{~K}-3$ & 37 & 74 & Tinggi & 15 & 64 & Sedang & 24 \\
\hline 4 & $\mathrm{~K}-4$ & 35 & 70 & Tinggi & 17 & 62 & Sedang & 21 \\
\hline 5 & K-5 & 39 & 78 & Tinggi & 19 & 72 & Tinggi & 18 \\
\hline 6 & K-6 & 37 & 74 & Tinggi & 13 & 60 & Sedang & 26 \\
\hline 7 & $\mathrm{~K}-7$ & 38 & 76 & Tinggi & 19 & 70 & Tinggi & 17 \\
\hline \multicolumn{2}{|c|}{ Rata-rata } & 39,14 & 75,14 & Tinggi & 18,57 & 66,85 & Sedang & \\
\hline
\end{tabular}

Pada tabel 2 digambarkan bahwa tingkat perilaku bullying saat pre-test 1 orang siswa berada pada tingkat sangat tinggi dan 6 orang siswa berada pada tingkat tinggi. Setelah mendapatakan treatment konseling kelompok teknik role playing (post-test) mengalami penurunan tingkat perilaku bullying menjadi 3 orang siswa berada dalam sangat rendah dan 4 orang siswa pada tingkat rendah. Pada tabel 3 hasil berbeda ditunjukan pada kelompok kontrol tingkat perilaku bullying saat pre-test 7 orang siswa berada pada tingkat tinggi. Setelah mendapatakan treatment konseling kelompok konvensional (placebo) mengalami penurunan tingkat perilaku bullying siswa menjadi 4 orang siswa berada pada tingkat sedang dan 3 orang siswa berada pada tingkat tinggi. Hasil ini menunjukkan bahwa perlakuan pada kelompok kontrol hanya berefek rendah dibandingkan dengan kelompok eksperimen, oleh karena itu dapat dikatakan bahwa konseling kelompok teknik role playing sangat berpengaruh dalam menurunkan perilaku bullying siswa.

Penjelasan di atas relevan dengan hasil penelitian sebelumnya bahwa konseling kelompok teknik role playing efektif dalam mengurangi perilaku bullying, penerapan metode role playing diterapkan dalam 4 kelompok dan setiap kelompok memiliki peran dan situasi yang berbeda, ada yang menjadi korban, pengganggu/pelaku, pengamat dan orang yang menyaksikan peristiwa bullying. Setiap anggota kelompok merasakan pengalaman pribadinya atau penyesalan terhadap korban dalam ingatan sebelumnya, sehingga semua anggota kelompok memahami potensi apa yang akan terjadi dari perilaku bullying (Gillesple, et al 2015). 
Penelitian relevan lainnya juga mengungkap bahwa dalam teknik role playing anggota kelompok diberi kesempatan memahami dampak buruk dari perilaku bullying serta merasan bagaimana menjadi korban bullying, hal ini dilakukan untuk menumbuhkan rasa empati terhadap teman dan juga memahami masalah sosial di sekitar lingkungan anggota kelompok (Adit, G. N., Hendriana, H., \& Rosita T 2019).Temuan ini juga memperkuat penelitian terdahulu akan keefektifan konseling kelompok teknik role playing, sebagaimana penelitian Maepin, Suarni \& Mudjijono (2013) tentang penerapan konseling kelompok pendekatan analisis transaksional teknik role playing untuk meminimalisir perilaku bullying siswa. Afiani, Rosra \& Mayasari (2018) untuk mengetahui pengaruh konseling kelompok terhadap intensi bullying siswa. Artyarini , Eva \& Fatimah (2018) tentang penerapan konseling kelompok dalam penelitian tindakan dengan munggunakan teknik role playing untuk mereduksi bullying siswa secara kolaboratif antara peneliti dan konselor sekolah.

\section{SIMPULAN}

Tingkat perilaku bullying siswa di SMP Negeri 1 Terisi Kabupaten Indramayu pada hasil pre-test baik kelompok eksperimen maupun kelompok kontrol rata-rata dalam kategori tinggi. Konseling kelompok teknik role playing berhasil menurunkan perilaku bullying siswa pada kelompok eksperimen mejadi kategori rendah dan sangat rendah. Hasil uji wilcoxon menunjukan bahwa konseling kelompok teknik role playing efektif dalam menurunkan perilaku bullying siswa. Sementara kelompok kontrol mengalami penurunan skor perilaku bullying menjadi sedang, hal ini menunjukan bahwa konseling kelompok menggunakan teknik role playing maupun tidak menggunakan teknik terbukti dapat mengurangi perilaku bullying siswa. Namun, penggunaan teknik dalam konseling kelompok memiliki keefektifan yang jauh lebih baik dibandungkan tidak menggunakan teknik. Saran untuk peneliti selanjutnya, peneliti dapat menambahkan variabel lain dalam penelitian ini atau mengganti responden dengan pendidikan lebih tinggi ataupun lebih rendah. Sedangkan untuk konselor sekolah penelitian ini bisa dijadikan bukti bahwa penggunaan teknik dalam melaksanakan konseling kelompok lebih memberikan hasil efektif.

\section{REFERENSI}

Afiani, S. D., Rosra, M., \& Mayasari, S. (2018). Pengurangan intensi bullying menggunakan layanan konseling kelompok. ALIBKIN (Jurnal Bimbingan Konseling), 6(3), 1-14.

Adit, G. N., Hendriana, H., \& Rosita, T. (2019). Bimbingan kelompok dengan teknik role playing untuk mengurangi perilaku bullying pada peserta didik SMP " $X$ " di Kota Bandung. FOKUS (Kajian Bimbingan \& Konseling dalam Pendidikan), 2(6), 213-227.

Ahmed, M. Z., Ahmed, O., \& Hiramoni, F. A. (2021). Prevalence and nature of bullying in schools of Bangladesh: A pilot study. Heliyon, 7(6), e07415.

Artyarini, A., Oktapiani, E., \& Fatimah, S. (2018). Penerapan teknik role playing dalam mengurangi perilaku bullying pada peserta didik MTs. FOKUS (Kajian Bimbingan \& Konseling dalam Pendidikan), 1(3), 94-102. 
Berg, R. C., Landreth, G. L., \& Fall, K. A. (2018). Group counseling: Concepts and procedures. New York: Routledge Taylor \& Francis Group.

Coloroso, B. (2007). The bully: The bullied, and The not so innocent bystander. New York: Weekly.

Ellis, A., \& MacLaren, C. (1998). Rational emotive behavior therapy: A therapist's guide. California: Impact Publisher.

Eyuboglu, M., Eyuboglu, D., Pala, S. C., Oktar, D., Demirtas, Z., Arslantas, D., \& Unsal, A. (2021). Traditional school bullying and cyberbullying: Prevalence, the effect on mental health problems and self-harm behavior. Psychiatry Research, 297, 113730.

Gillespie, G. L., Brown, K., Grubb, P., Shay, A., \& Montoya, K. (2015). Qualitative evaluation of a role play bullying simulation. Journal of Nursing Education and Practice, $5(7), 73-80$.

Maepın, N. K., Suarnı, N. K., \& Mudjijono, M. M. (2013). Penerapan konseling analisis transaksional dengan teknik role playing untu meminimalisasi perilaku bullying siswa. Jurnal Ilmiah Bimbingan Konseling Undiksha, 1(1), 1-10.

Nansel, T. R., Overpeck, M., Pilla, R. S., Ruan, W. J., Simons-Morton, B., \& Scheidt, P.(2001). Bullying behaviors among US youth: Prevalence and association with psychosocial adjustment. Journal of the American Medical Association, 285(16), 20942100.

Olweus, D.(1993). Bullying at school: What we know and what we can do. Malden, MA: Blackwell Publishing..

Purnaningrum, A. W., Purwanto, E., \& Ja'far, M. (2017). Konseling kelompok dengan teknik role playing untuk membentuk sikap negatif siswa terhadap perilaku bullying. Jurnal Bimbingan Konseling, 6(2), 101-105.

Sánchez, F. C., Romero, M. F., Navarro-Zaragoza, J., Ruiz-Cabello, A. L., Frantzisko, O. R., \& Maldonado, A. L. (2016). Prevalence and patterns of traditional bullying victimization and cyber-teasing among college population in Spain. BMC Public Health, 16(1), 1-10.

Sari, P. (2010). Coping stress pada remaja korban bullying di sekolah " $\mathrm{X}$ ". Jurnal Psikologi, $8(2), 75-81$.

Swearer, S. M., \& Hymel, S. (2015). Understanding the psychology of bullying: Moving toward a social-ecological diathesis-stress model. American Psychologist, 70(4), 344.

Trotzer, J. P. (2006). The counselor and the group: Integrating theory, training, and practice. New York: Routledge.

Volk, A. A., Dane, A. V., \& Marini, Z. A. 2014. What is bullying? A theoretical redefinition. Developmental Review, 34(4), 327-343.

Yahya, N., \& Mustaffa, M. S. (2012). Application of rational emotive behaviour therapy in addressing the problems of bulliying in the school: A case study. Journal of Educational Psychology \& Counseling, 6(1), 123-128. 